\title{
ANALISIS SUSUT HASIL PADI PADA LAHAN KERING DAN IMPLIKASINYA TERHADAP PEREKONOMIAN DI KABUPATEN LOMBOK TENGAH
}

\author{
Suwati, Budy Wiryono, Erni Romansyah \\ Prodi Teknik Pertanian, Faperta Universitas Muhammadiyah Mataram, \\ suwati@ummat.ac.id
}

\section{INFO ARTIKEL}

\section{Riwayat Artikel:}

Diterima: 12-05-2018

Disetujui: 28-06-2018

\section{Kata Kunci:}

susut hasil

produksi padi

lahan kering

analisis faktor

dampak ekonomi

\section{ABSTRAK}

\begin{abstract}
Abstrak: Penanganan pascapanen padi merupakan upaya sangat strategis dalam rangka mendukung peningkatan produksi padi. Masalah utama yang dihadapi dalam penanganan pascapanen padi adalah tingginya susut (losses) baik secara kuantitatif maupun kualitatif. Penelitian ini bertujuan untuk mengkaji besaran susut hasil panen padi tahap (perontokkan, pengeringan, penggilingan) dan mengetahui dampak ekonomi susut hasil panen padi di Kabupaten Lombok Tengah. Untuk itu telah dilakukan penelitian di Kecamatan Janapria, Kecamatan Praya, dan Kecamatan Pujut Kabupaten Lombok Tengah pada bulan Januari Februari 2018. Penelitian menggunakan metode deskriptif dengan analisis faktor untuk menganalisis variabel yang berpengaruh terhadap susut hasil padi dab melihat pendapatan petani dalam melihat dampak ekonomi yang diakibatkan oleh susut hasil padi. Hasil penelitian menunjukkan bahwa rata-rata besaran susut hasil padi di Kabupaten Lombok Tengah pada tahap perontokkan 0.24 persen, tahap pengeringan 0.07 persen, dan tahap penggilingan 0.60 persen. Berdasarkan hasil analisis faktor dapat disimpulkan bahwa variabel pendapatan dan variabel luas lahan yang berpengaruh terhadap susut hasil padi di Kabupaten Lombok Tengah. Selanjutnya rata-rata kehilangan uang petani di Kabupaten Lombok Tengah sebesar Rp. 126.782 yang berarti bahwa setiap luasan hektar lahan usahatani, rumahtangga tani akan mengalami kerugian fisik berupa kehilangan pendapatan.
\end{abstract}

\section{A. LATAR BELAKANG}

Penanganan pascapanen padi merupakan upaya sangat strategis dalam rangka mendukung peningkatan produksi padi. Kontribusi penanganan pascapanen terhadap peningkatan produksi padi dapat tercermin dari penurunan kehilangan hasil dan ter-capainya mutu gabah/ beras sesuai persyaratan mutu. Setyono (2010) menyatakan masalah utama dalam penanganan pascapanen padi adalah tingginya kehilangan hasil serta gabah dan beras yang dihasilkan bermutu rendah. Hal tersebut terjadi pada tahapan pemanenan, perontokan dan pengeringan.

Masalah utama yang dihadapi dalam penanganan pascapanen padi adalah tingginya susut (losses) baik secara kuantitatif maupun kualitatif. Permasalahan tersebut berakibat adanya kecenderungan tidak memberikan insentif kepada petani untuk memperbaiki tingkat pendapatannya (Hasbullah 2007). Padi/gabah yang kadar airnya tinggi mempunyai sifat mudah rusak dan akan mengalami susut pada saat penanganan pascapanen dan pengolahan.
Penanganan pascapanen yang baik akan berdampak positif terhadap kualitas gabah konsumsi, benih, dan beras. Oleh karena itu, penanganan pascapanen perlu mengikuti persyaratan Good Agricultural Practices (GAP) dan Standard Operational Procedure (SOP) (Setyono et al. 2006). Dengan demikian, beras yang dihasilkan memiliki mutu fisik dan mutu gizi yang baik sehingga mempunyai daya saing yang tinggi (Setyono et al. 2006).

Mengacu pada data BPS (1996) susut hasil panen padi atau tingkat kehilangan padi saat panen cukup tinggi, dan secara nasional belum mencapai $10,82 \%$. Angka ini mengalami penurunan dibanding tahun 1995/1996 yang tingkat kehilangan hasil padi pasca panen mencapai 19,98\%. Kehilangan hasil panen padi dipengaruhi oleh (1) varietas, (2) kadar air gabah saat panen, (3) alat panen, (4) cara panen, (5) cara/alat perontokan, dan (6) sistem pemanenan padi (Rumiati,1982).

Beberapa penelitian terdahulu yang dilakukan belum banyak mengungkap tentang dampak ekonomi yang ditimbulkan oleh susut hasil padi (Nugraha, dkk., 
2007; Listyawati, 2007; Rahadjo, dkk., 2012) terutama keuntungan petani secara keseluruhan. Secara matematis bila dihitung dampak ekonomi dari susut hasil padi untuk setiap kehilangan 1 butir gabah bernas (sebasar 0,022 gram) gabah kering panen, yang berarti telah terjadi kehilangan hasil sebesar 10,82\% berdasarkan perhitungan susut hasil nasional (Kementerian Pertanian, 2012).

Dinas Pertanian Tanaman Pangan dan Hortikultura (2010) Provinsi Nusa Tenggara Barat melaporkan kehilangan hasil padi pada tahun 2010 sebesar $649,20 \mathrm{~kg} / \mathrm{Ha}$, mengacu pada harga gabah tahun 2012 sebesar Rp. 3.400,- maka kerugian yang ditimbulkan berupa kehilangan pendapatan berupa gabah yang di akibatkan oleh perlakuan dalam usahatani dalam proses pemanenan, penumpukan, perontokan, pengeringan dan penggilingan sebesar Rp. 2.207.280,/Ha dengan luas lahan sawah tadah hujan di Kabupaten Lombok Tengah sebesar 74.938 ha.

Berdasarkan uraian di atas, maka akan dilakukan penelitian yang berjudul "Analisis Susut Hasil Padi Pada Lahan Kering dan Implikasinya Terhadap Perekonomian di Kabupaten Lombok Tengah".

\section{B. METODE PENELITIAN}

Penelitian ini menggunakan metode deskriptif dilaksanakan pada bulan Januari-Februari 2018 di 3 (tiga) Kecamatan; Kecamatan Janapria, Kecamatan Praya, dan Kecamatan Pujut di Kabupaten Lombok Tengah. Pemilihan 3 (tiga) Kecamatan ini secara sengaja karena memiliki luas lahan kering untuk tanaman padi sawah yang luas di Kabupaten Lombok Tengah. Unit analisis dalam penelitian ini adalah rumah tangga petani padi sawah lahan tadah hujan di Kabupaten Lombok Tengah. Jumlah responden ditentukan secara sengaja sejumlah 30 orang petani responden. Dalam mengukur susut hasil perontokkan, susut hasil pengeringan, dan susut hasil penggilingan digunakan rumus matematis sebagai berikut :

$$
\begin{aligned}
& \text { Susut Perontokkan } \\
& \mathrm{SPr}=\frac{\left(\mathrm{T}_{1}+\mathrm{T}_{2}+\mathrm{T}_{a}\right)}{\left(\mathrm{T}_{0}+\mathrm{T}_{1}+\mathrm{T}_{2}+\mathrm{T}_{2}\right)} \times 100 \%
\end{aligned}
$$

Keterangan :

$\begin{array}{lll}\mathrm{SPr} & : & \text { susut perontokan } \\ \mathrm{T}_{\mathrm{o}} & : & \text { gabah hasil perontokan } \\ \mathrm{T}_{1} & ; & \text { gabah yang terlempar di luar alas petani } \\ \mathrm{T}_{2} & \text { : } & \text { gabah yang masih melekat pada jerami } \\ & \text { dan tidak terontok } \\ \mathrm{T}_{3} & \text { : } & \text { gabah yang terbawa kotoran }\end{array}$

\section{Susut Pengeringan dan Konversi Pengeringan}

$$
\begin{aligned}
& \text { Susut Pengeringan } \\
& \mathrm{SK}=\frac{\mathrm{BKG}_{\mathrm{b}}-\mathrm{BKG}_{\mathrm{k}}}{\mathrm{BG}_{\mathrm{k}}} \times 100 \%
\end{aligned}
$$

Keterangan :

$\begin{array}{ll}\mathrm{SK} & \text { : susut pengeringan } \\ \mathrm{BKG}_{\mathrm{b}} & \text { : berat kering gabah sebelum } \\ & \text { pengeringan } \\ \mathrm{BKGkb} & \text { : berat kering pengeringan } \\ \mathrm{BG}_{\mathrm{k}}: & \text { berat gabah setelah pengeringan (GKG) }\end{array}$

$$
\begin{aligned}
\mathrm{BKG}_{\mathrm{b}}=\frac{100-\mathrm{KA}_{\mathrm{b}}}{100} \times \mathrm{BG}_{\mathrm{b}} \\
\mathrm{BKG}_{\mathrm{k}}=\frac{100-\mathrm{KA}_{\mathrm{k}}}{100} \times \mathrm{BG}_{\mathrm{k}}
\end{aligned}
$$

Keterangan:

$\mathrm{KA}_{\mathrm{b}}$ : kadar air gabah sebelum pengeringan (GKP)

$\mathrm{KA}_{\mathrm{k}}$ : kadar air gabah pengeringan (GKG)

$\mathrm{BG}_{\mathrm{b}}$ : berat gabah sebeium pengeringan (GKP)

$\mathrm{BG}_{\mathrm{k}}$ : berat gabah setelah pengeringan (GKG)

$$
\begin{aligned}
& \text { Konversi Pengeringan } \\
& \mathrm{KKG}=\frac{\mathrm{BG}_{\mathrm{k}}+\left(\mathrm{BKG}_{\mathrm{b}}-\mathrm{BKG}_{\mathrm{k}}\right.}{\mathrm{BG}_{\mathrm{b}}} \times 100 \%
\end{aligned}
$$

Keterangan : KKG : konversi pengeringan gabah

\section{Susut Penggilingan dan Rendemen Penggilingan}

\section{Susut Penggilingan \\ $\mathrm{Spg}_{\mathrm{ijk}}=\mathrm{Rlb}_{\mathrm{ijk}}-\mathrm{RIp}_{\mathrm{ijk}}$}

Keterangan :

$\mathrm{Spg}_{\mathrm{ijk}}$ : susut penggiiingan

i : varietas

$\mathrm{j} \quad$ : teknologi penggilingan

$\mathrm{k} \quad$ : derajat sosoh

$\mathrm{R}_{\mathrm{Ib}}$ : rendemen laboratorium

$\mathrm{R}_{\mathrm{Ip}}$ : rendemen lapang

$$
\begin{aligned}
& \mathrm{R}_{\mathrm{Ib}}=\frac{\text { Berat beras giling laboratorium }}{\text { Berat gabah laboratorum }} \times 100 \% \\
& \mathrm{R}_{\mathrm{Ip}}=\frac{\text { Berat beras giling lapang }}{\text { Berat gabah lapang }} \times 100 \%
\end{aligned}
$$

$$
\begin{aligned}
& \text { Rendemen Penggilingan } \\
& \mathrm{RGL}=\frac{\text { Berat beras hasil penggilingan }}{\text { Berat gabahyang digiling }} \times 100 \%
\end{aligned}
$$

Selanjutnya hasil kuesioner dan wawancara ditentukan 6 (enam) variabel yang akan dilihat berkaitan dengan susut hasil padi, yaitu : pendapatan, kepemilikan lahan, pendidikan, jumlah tanggungan keluarga, tenaga kerja dan waktu yang digunakan. Perhitungan data menggunakan skoring dan dianalisis menggunakan analisis faktor. Sedangkan untuk melihat dampak ekonomi dari susut hasil dilakukan mengurangi pendapatan yang diterima dengan susut hasil yang diperoleh melalui wawancara dan kuesioner serta perhitungan menggunakan perangkat lunak Excel for windows

\section{HASIL DAN PEMBAHASAN}

1. Susut Hasil Padi Tahap Perontokkan, Pengeringan, dan Penggilingan

Kegiatan pascapanen meliputi kegiatan pemanenan, perontokan, pengangkutan, pengeringan, penggilingan, penyimpanan, dan pemasaran. Berdasarkan hasil beberapa penelitian menunjukkan bahwa kehilangan hasil pasca panen sampai saat ini masih cukup tinggi, yaitu lebih dari 20\%. Titik kritis kehilangan hasil terjadi pada 
tahapan pemanenan dan perontokan. Dengan tingkat kehilangan yang masih cukup tinggi, yaitu pada tahapan pemanenan kehilangan masih berkisar 9\%, dan pada tahapan perontokan masih lebih dari 4\% (Setyono et al, 1995). Dalam penelitian ini yang diamati adalah susut hasil tahap prontokkan, susut hasil tahap pengeringan, dan susut hasil tahap penggilingan yang dilaksanakan di Kabupaten Lombok Tengah.

Berikut ini merupakan gambaran umum perbandingan hasil susut (perontokkan, pengeringan, dan penggilingan) berdasarkan penelitian dengan dengan standar nasional susut hasil padi pada tabel 1 .

TABEL 1.

Perbandingan Susut Hasil Padi (Perontokkan, Pengeringan, Dan Penggilingan) Hasil Penelitian Dengan Standar Nasional

\begin{tabular}{llccc}
\hline No & Susut Padi & $\begin{array}{c}\text { Standar } \\
\text { Nasional } \\
(\%)\end{array}$ & $\begin{array}{c}\text { Hasil } \\
\text { Penelitian } \\
(\%)\end{array}$ & Selisih \\
\hline 1 & Perontokkan & 5 & 0.24 & 4.76 \\
\hline 2 & Pengeringan & 2.1 & 0.05 & 2.05 \\
\hline 3 & Penggilingan & 2.2 & 0.60 & 1.60 \\
\hline
\end{tabular}

Sumber : Hasil Survey Nasional BPS dengan Kementerian Pertanian RI (2012) serta Data Primer yang diolah

Berdasarkan Tabel 1 diperoleh bahwa ratarata susut hasil perontokkan di lokasi penelitian sebesar $0,24 \%$ nilainya jauh dari susut hasil perontokkan secara nasional yakni sebesar 5\%. Tingginya perbedaan kehilangan hasil pada tahap perontokkan secara Nasional disebabkan masih banyaknya gabah yang tertinggal pada malai sehingga menyebabkan susut hasil perontokkan menjadi lebih tinggi nilai. Sedangkan pada petani responden yang diteliti gabah yang tertinggal pada malai lebih sedikit. Hal ini sesuai dengan pendapat Setyono dan Hasanuddin (1997) selama perontokan, susut dapat terjadi karena adanya gabah yang tertinggal pada malai, juga kerusakan mekanis yang disebabkan oleh peralatan atau mesin yang digunakan.

Tabel 1 juga menunjukkan bahwa rata-rata susut hasil pengeringan di lokasi penelitian lebih rendah dari susut hasil pengeringan secara nasional. selisihnya sebesar 2,05\%. Perbedaan hasil susut pengeringan secara nasional dan petani responden kemungkingan disebabkan karena intensitas pembalikan dan penggunaan alas jemur. Petani responden sebagian besar melakukan pembalikan padi kurang dari 2 (dua) kali sedangkan penelitian lain melakukan pembalikan padi lebih dari 2 (dua) kali sehingga menyebabkan banyak gabah yang tercecer. Selain itu juga, penggunaan lantai jemur oleh peneliti lain dapat meningkatkan susut hasil padi tahap pengeringan sedangkan petani responden menggunakan alas jemur terpal dimana padi tidak banyak tercecer sehingga nilai susut pada tahap pengeringan lebih kecil dari standar nasional. Sejalan dengan pendapat tersebut, Badan Ketahanan Pangan (2010) dalam laporan tahunan "Antisipasi Kerawanan Pangan NTB Dengan Meminimalisir Susut Hasil Pangan" melaporkan bahwa kehilangan hasil pada tahapan pengeringan umumnya disebabkan oleh (1) fasilitas penjemuran seperti lantai jemur maupun alas lainnya yang kurang baik, sehingga banyak gabah yang tercecer dan terbuang saat proses penjemuran dan (2) adanya gangguan hewan seperti ayam, burung, kambing dan lain-lain.

Selanjutnya pada tahap penggilingan pada tabel1 menunjukkan selisih 1,6\% antara susut hasil penggilingan petani responden dengan susut hasil pengeringan secara nasional. Terjadi perbedaan yang tinggi susut hasil secara nasional, petani responden, dan peneliti lain disinyalir disebabkan karena perbedaan orientasi kegunaan. Peneliti lain mempertimbangkan kualitas beras sehingga pase penggilingan sampe pada 2 pase sedangkan petani responden yang diteliti lebih untuk kegunaan konsumsi sendiri artinya cukup pada 1 pase. Hal ini mempengaruhi susut yang diperoleh.

\section{Analisis Faktor Susut Hasil Padi}

Potensi kehilangan hasil khususnya pada saat perontokkan, pengeringan, dan penggilingan memang sangat bervariasi. Namun untuk melihat beberapa variabel independen dalam susut hasil yang saling berhubungan (interrelationship) satu dengan yang lainnya, sehingga bisa dibuat kumpulan variabel yang lebih sedikit dari jumlah variabel awal sehingga akan mudah diinterpretasikan faktor yang berpengaruh terbesar, besar, sedang, cukup, dan tekecil terhadap susut hasil padi (Suharjon, 2008)

Berdasarkan hasil kuesioner diperoleh 6 (enam) variabel independen, yaitu; pendapatan, luas lahan yang dimiliki, pendidikan, jumlah tanggungan keluarga, jumlah tenaga kerja, dan waktu yang dibutuhkan pada saat pascapanen. Selanjutnya, hasil perhitungan dari keenam variabel tersebut dikategorikan dalam bentuk skoring. Setelah terbentuk skoring dari 6 (enam) variabel tersebut dianalisis menggunakan analisis faktor dengan hasil sebagai berikut :

TABEL 2.

Hasil Uji Korelasi Antarvariabel Independen Ada Pada Output Kmo And Bartlett's Test

\begin{tabular}{lll}
\hline \multicolumn{2}{l}{$\begin{array}{l}\text { Kaiser-Meyer-Olkin Measure } \\
\text { of Sampling Adequacy. }\end{array}$} & .751 \\
\hline Bartlett's & Approx. \\
Test of Sphericity & $\begin{array}{l}\text { Chi- } \\
\text { Square }\end{array}$ & 110.403 \\
\cline { 2 - 3 } & Df & 15 \\
\cline { 2 - 3 } & Sig. & .000 \\
\hline
\end{tabular}

Hasil perhitungan pada Tabel 2 menunjukkan besaran nilai Barlett Test of Sphericity adalah 110,403 pada signifikan o,ooo yang berarti pada penelitian ini ada korelasi yang sangat signifikan antar variabel dan hasil perhitungan Kaiser-MeyerOlkin Measure of Sampling Adequacy (KMO) sebesar 0,751 sehingga kecukupan sampel termasuk kategori yang menengah.

Selanjutnya guna menentukan seberapa banyak faktor yang mungkin terbentuk dapat dilihat pada Tabel 3 dibawah ini. 
TABEL 3 .

Total Variance Explained

Extraction Sums of

\begin{tabular}{cc} 
Initial Eigenvalues & Squared Loadings \\
\hline$\%$ of & $\%$ of
\end{tabular}

Component Total Variance Cum \% Total Variance Cum \%

\begin{tabular}{|c|c|c|c|c|c|}
\hline 1 & 3.475 & 57.925 & $57.925 \quad 3.475$ & 57.925 & 57.925 \\
\hline 2 & 1.408 & 23.464 & 81.3891 .408 & 23.464 & 81.389 \\
\hline 3 & .547 & 9.120 & 90.509 & & \\
\hline 4 & .293 & 4.879 & $95 \cdot 387$ & & \\
\hline 5 & .158 & 2.631 & 98.018 & & \\
\hline 6 & .119 & 1.982 & 100.000 & & \\
\hline & $\begin{array}{l}\text { ethod } \\
\text { nalys }\end{array}$ & incipal & & & \\
\hline
\end{tabular}

Tabel 3 adalah daftar nilai-eigen yang dihubungkan dengan setiap komponen sebelum ekstraksi dan setelah rotasi. Sebelum ekstraksi ada 6 komponen dalam himpunan data yang sesuai dengan Extraction Sums of Squared Loading. Ekstraksi dilakukan ke dalam 2 faktor dengan varians pada faktor pertama sebesar 57,925 dan secara kumulatif untuk keseluruhan 2 komponen adalah 81,389\%. Pada kolom Rotation Sums of Square Loadings dapat dilihat nilai-eigen setelah rotasi. Kolom ini menjelaskan bentuk pengaruh terhadap struktur faktor dengan penyamaan kepentingan dari ke 2 faktor. Agar lebih jelas variabel mana masuk ke faktor mana, bisa dilihat Tabel Rotated Component Matrix sebagai berikut:

TABEL 4.

Rotated Component Matrix

\begin{tabular}{lcr}
\hline \multicolumn{3}{c}{ Component } \\
\hline \multicolumn{1}{c}{1} & \multicolumn{1}{c}{} \\
\hline Pendapatan & .893 & .254 \\
Lahan & .919 & -.019 \\
Pendidikan & .256 & -.840 \\
Jlm._Klg & .331 & .782 \\
Ten_Kerja & .924 & -.177 \\
Wkt_Susut & .891 & .056 \\
\hline Extraction Method: Principal Component \\
Analysis. \\
Rotation Method: Varimax with Kaiser \\
Normalization.
\end{tabular}

Kedua faktor yang terbentuk dapat bagi kedalam faktor usahatani (pendapatan, lahan, tenaga kerja, dan waktu susut) dan faktor karakteristik petani (pendidikan dan jumlah tanggungan keluarga).

Baik faktor usahatani ataupun faktor karakteristik petani memiliki korelasi bervariasi terhadap susut hasil padi setelah dilakukan transformasi tiap-tiap komponen. Namun yang harus menjadi acuan dalam interpretasi hasil analisis faktor yakni Tabel 4 yang menampilkan nilai-eigen yang menunjukkan ada 2 (dua) variabel saja yang memenuhi prasyarat nilai-eigen lebih besar dari satu, yakni pendapatan dengan nilaieigen sebesar 3,475 artinya mampu menjelaskan varian total sebesar $57,925 \%$, dan luas lahan nilaieigen sebesar 1,408 artinya mampu menjelaskan varian total sebesar $23,464 \%$. Sedangkan variabel yang lain tidak berpengaruh (pendidikan, jumlah tanggunga keluarga, tenaga kerja, dan waktu susut) karena nilai-eigennya kurang dari satu dan hanya mampu menjelaskan varian totalnya dibawah $10 \%$. Hal ini sesuai dengan pendapat Suharjon (2008) yang mengatakan bahwa nilai-eigen lebih besar dari satu dapat menjelaskan persentase total varian variabel yang mempengaruhi. Berikut ini deskripsi dari masing-masing variabel independen.

\section{Dampak Ekonomi Susut Hasil Padi}

Dalam menghitung dampak ekonomi terhadap susut hasil padi di Kabupaten Lombok Tengah maka penulis menggunakan parameter nilai total kehilangan padi (perontokkan, pengeringan, dan penggilingan) dikalikan dengan harga gabah pada saat sekarang (Rp. 3400/kg). berdasarkan rumus matematik sederhana tersebut didapatkan bahwa total susut hasil padi rata-rata di Kabupaten Lombok Tengah sebesar $37.29 \mathrm{~kg} / \mathrm{ha}$ dimana nilai kehilangannya bila dikonversikan kedalam rupiah sebesar Rp. 126.782. Kehilangan uang sebesar Rp. 126.782 berarti setiap luasan hektar lahan usahatani, rumahtangga tani akan mengalami kerugian fisik berupa kehilangan pendapatan berupa gabah yang di akibatkan oleh perlakuan dalam usahatani dalam proses perontokan, pengeringan dan penggilingan.

Selanjutnya, berdasarkan data yang diperoleh menunjukkan rata-rata susut hasil padi di Kabupaten Lombok Tengah sebesar 0,9 persen. Hal ini tentunya sangat rendah bila dibandingkan dengan rata-rata kehilangan hasil padi secara nasional menurut Kementerian Pertanian tahun 2012 sebesar 10,82 persen. Berdasarkan data tersebut selanjutnya dapat dihitung rata-rata susut hasil di Kabupaten Lombok Tengah dengan data nasional. Diketahui luas lahan sawah tadah hujan yang ditanami padi sebesar 11.332 ha dengan ratarata produktivitas sebesar 6,1 ton per hektar. Sedangkan untuk lokasi penelitian yang masuk dalam kategori lahan sawah tadah hujan sebesar 19,5 ha dengan rata-rata produktivitas 3,23 ton/ha. Total GKP di Kabupaten Lombok Tengah yang diperoleh sebesar $69.125,2$ ton. Sedangkan total GKP dilokasi penelitian diperoleh sebesar 62,985 ton.

Selanjutnya, dari hasil tersebut bisa diasumsikan bahwa bila susut hasil yang diperoleh di Kabupaten Lombok Tengah sebesar 0,9 persen dan susut hasil secara nasional sebesar 10,82 persen. Dengan total GKP telah diperoleh maka dapat mencari kehilangan hasil di Kabupaten Lombok Tengah sebesar 622,1 ton, kehilangan hasil di lokasi penelitian sebesar 0,57 ton, dan kehilangan hasil secara nasional sebesar 59289,6 ton. 
Walaupun jumlah kehilangan hasil padi yang dialami petani di Kabupaten Lombok Tengah sangat rendah namun hal tersebut akan berdampak pada tingkat pendapatan perkapita yang diterima petani sekaligus kemampuan memenuhi kebutuhan hidup selama setahun dan pada kondisi iklim yang tidak menentu dapat berakibat terjadinya kerawanan pangan. Potensi kehilangan hasil padi bila tidak ditangani dengan serius akan sangat berpengaruh terhadap stok pangan daerah/nasional.

\section{KESIMPULAN DAN SARAN}

Terbatas pada pembahasan maka dapat ditarik simpulan sebagai berikut :

1. Rata-rata besaran susut hasil padi di Kabupaten Lombok Tengah pada tahap perontokkan 0.24 persen, tahap pengeringan 0.07 persen, dan tahap penggilingan 0.60 persen. Berdasarkan hasil analisis faktor dapat disimpulkan bahwa variabel pendapatan dan variabel luas lahan yang berpengaruh terhadap susut hasil padi di Kabupaten Lombok Tengah.

2. Rata-rata kehilangan uang petani di Kabupaten Lombok Tengah sebesar Rp. 126.782 yang berarti bahwa setiap luasan hektar lahan usahatani, rumah tangga tani akan mengalami kerugian fisik berupa kehilangan pendapatan berupa gabah yang di akibatkan oleh perlakuan dalam usahatani pada tahap perontokan, pengeringan dan penggilingan.

\section{DAFTAR RUJUKAN}

[1] Biro Pusat Statistik, 1996. Survei susut pascapanen MT. 1994/1995 KerjasamaBPS, Ditjen Tanaman Pangan, Badan Pengendali Bimas, Bulog, Bappenas, IPB,dan Badan Litbang Pertanian

[2] Badan Ketahanan Pangan, 2010. Antisipasi Kerawanan Pangan NTB Dengan Meminimalisir Susut Hasil Pangan. Laporan Tahun BKP Provinsi NTB Tahun 2010. Mataram.

[3] Dinas Pertanian TPH NTB, 2010. Penekanan susut dan peningkatan rendemen gabah/beras di NTB.

[4] Hasbullah R, 2007. Gerakan Nasional Penurunan Susut Pascapanen, Suatu Upaya Menanggulangi Krisis Pangan.

[5] Kementerian Pertanian, (2012), Pedoman Survei Susut Hasil Padi Tahun 2012, Kementerian Pertanian Direktorat Jenderal Tanaman Pangan 2012.

[6] Listyawati, 2007. KAJIAN Susut Pasca Panen Dan Pengaruh Kadar Air Gabah Terhadap Mutu Beras Giling Varietas Ciherang (Studi Kasus di Kecamatan Telagasari, Kabupaten Karawang). Skripsi - IPB Press. Bogor.

[7] Nugraha S, Thahir R, Sudaryono. 2007. Keragaan Kehilangan Hasil Pascapanen Padi Pada 3 (tiga) Agroekosistem. Buletin Teknologi Pascapanen Pertanian Vol. (3) Hal .42-49. Kementan RI. Jakarta.

[8] Raharjo B, Hadiyanti D, Kodir KA, 2012. Kajian Kehilangan Hasil Pada Pengeringan dan Penggilingan Padi di Lahan Pasang Surut Sumatera Selatan. Jurnal Lahan Suboptimal. ISSN2252-6188. Vol. 1, No.1: 7282, April 2012. Universitas Negeri Medan Press. Medan.

[9] Rumiati, 1982. Cara panen dan perontokan padi VUTW untuk menentukan jumlah kehilangan. Laporan Kemajuan Penelitian Seri Teknologi Lepas PanenNo. 13 Sub Balittan Karawang.
[10] Setyono, A., S. Nugraha dan A. Hasanuddin, 1997. Usaha pengembangan pemanenan padi dengan sistem beregu. Seminar Apresiasi Hasil Penelitian. Balai Penelitian tanaman Padi. Sukamandi, 23 - 25 Agustus 1995.

[11] Setyono, A., 2006. Teknologi Penanganan Pascapanen Padi. Balai Penelitian. Tanaman Padi Sukamandi.

[12] Setyono, A., 2010. Perbaikan Teknologi Pascapanen Dalam Upaya Menekan Kehilangan Hasil Padi. Jurnal Pengembangan Inovasi Pertanian.3(3):212-226. Kementan RI. Jakarta.

[13] Suharjon, B., 2008. Analisis Regresi Terapan Dengan SPSS, Graha Ilmu, Yogyakarta 